ТУЛЕЙ Ю.Л., інженер (ПАТ «Українська залізниця»)

\title{
Математичне моделювання та експериментальні дослідження роботи дерев'яних шпал під дісю просторових навантажень
}

У статті наведено результати експериментальних робіт з досліджень пружних опорів дерев'яних шпал просторовим переміщенням під дією навантажень від рухомого складу. Отримано емпіричні залежності змін коефіцієнтів постілі дерев'яних шпал, коефіцієнтів їх вигину та горизонтальної поперечної жорсткості під час експлуатації колії. Враховано інші умови експлуатації, насамперед рівень діючих осьових навантажень.

Дослідження просторових сил взаємодії колії та рухомого складу дає змогу не тільки отримувати числові їх значення, але й цілеспрямовано впливаючи на характеристики колії та рухомого складу досягати оптимальних значень циих сил.

Ключові слова: дисипативні характеристики, дерев'яні шпали, горизонтальна поперечна жорсткість, рухомий склад.

\begin{abstract}
Вступ
Ланкова колія на дерев'яних шпалах на магістральних залізницях України застосовується в особливо важких умовах експлуатації - кривих малих радіусів, на великих уклонах та в умовах шахтних розробок. У таких умовах експлуатації виникають значні сили дії рухомого складу на колію, у першу чергу вертикальні та горизонтальні поперечні. Це призводить до підвищеного зносу як елементів колії (знос робочої грані головки рейки), так і зносу рухомого складу (знос робочої грані гребеня колеса).

Для визначення заходів боротьби 3 такими явищами необхідно провести дослідження сил дії рухомого складу на колію, що потребує знання просторових пружних характеристик рейкових опор. Складовими таких характеристик $є$ пружні сили опору переміщенням шпал.
\end{abstract}

\section{Аналіз досліджень і публікацій}

Пружну складову сил опору переміщенням шпал у вертикальній площині, $\kappa H$, в даний час прийнято визначати як

$$
R_{z}=C_{z u} \cdot Z_{p}=C_{y \sigma} \cdot \alpha \cdot \Omega_{u} \cdot y_{p}
$$

де $C_{z u}$ - складова вертикальної жорсткості рейкової опори, яка залежить від пружних властивостей шпали при вигинанні під дією вертикальних сил і пружних властивостей баластного шару й земляного полотна, $\kappa H / \mu$

$Z_{p} \quad$ - вертикальні переміщення шпали в підрейковому перерізі під дією сили $R_{z}, M$;

(C) Ю.Л. Тулей, 2016
$C_{z}$ - коефіціент постілі шпали, $\kappa H / \mathrm{s}^{3}$;

$\alpha$ - коефіцієнти вигину шпали;

$\Omega_{u}$ - площа полушпали, $\mu^{2}$.

Тоді складова вертикальної жорсткості рейкової опори, залежна від пружних властивостей шпали та іiі основи (далі - вертикальна жорсткість шпали), рівна

$C_{z}=C_{z \delta} \cdot \alpha \cdot \Omega_{u}$

Вплив пружних властивостей шпал та їх основи на формування вертикальної жорсткості колії дуже істотний, що наголошується багатьма дослідниками. Так, розрахунки, виконані в [1], показали, що частка цього параметра у формуванні модуля пружності колії 3 дерев'яними шпалами в літніх умовах складає від 77 до $90 \%$. У дослідах, проведених на залізницях ФРН [2], установлено, що питома вага шпал та їх основи в загальній вертикальній деформації колії на дерев'яних шпалах рівна $80 \%$.

У зимовий час, при промерзлому баласті й земляному полотні, жорсткість колії зростає в 1,5 [3], а за іншими даними, - у $2-3$ рази [4].

Експериментальному визначенню значень коефіцієнта постілі шпали було присвячено багато робіт [5-7 та ін.]. В основному наведені значення параметра $C_{y б}$ при статичному навантаженні колії, оскільки методи визначення динамічних жорсткостей ще недостатньо вивчені й визначені. Відомі, наприклад, методи визначення динамічних параметрів, запропоновані в роботах [8] і [9]. Наголошується, що при динамічних навантаженнях значення коефіцієнта постілі можуть складати $70 \%$, а в деяких випадках $60 \%$ від значень цієї величини при статичному навантаженні. Теоретичне обгрунтовування цього явища в результаті дії вібрації баласту наведено в [10]. 
І Н Ф О Р М А ЦІ ЙН О - КЕ Р У ЮЧ І С И С Т Е М И Н А 3 А Л І З Н ИЧ Н О М У Т Р А Н С П О Р Т І

У процесі експлуатації у міру ущільнення й забруднення баласту коефіцієнт постілі шпал зростає на $40-80 \%$ [7].

Коефіцієнтом вигину шпали прийнято називати [4] відношення середньої по довжині шпали осідання під дією вертикальних сил до їі осідання в підрейковому перерізі. Правила розрахунків залізничної колії на міцність і стійкість [3] рекомендують для дерев'яних шпал улітку приймати значення 0,881 ; узимку - 0,820. Для умов магістральних залізниць значення коефіцієнта постілі дерев'яних шпал рекомендується приймати в межах 65 - 85 мПа/м для літніх і 120 180 мПа/м для зимових умов.

Інформація про сили опору поперечним переміщенням шпал у баласті важлива при дослідженні взаємодії колії й рухомого складу, стійкості колії під дією повздовжніх сил. За оцінкою деяких дослідників (наприклад [11]), до 60-65\% загального опору рейко-шпальної решітки вигину в горизонтальній площині забезпечують сили опору баласту поперечному зсуву залізобетонних шпал. При цьому важливо знати, як сили опору змінюються в процесі експлуатації колії та як впливає на їх величину вертикальне навантаження при русі рухомого складу.

На цей час немає достовірних даних про зміни коефіцієнтів постілі дерев'яних шпал під час експлуатації колії та інформації про вплив характеристик рухомого складу, насамперед осьових навантажень, на ці параметри.

Практично немає інформації про опір рейкових опор горизонтальним поперечним навантаженням.

\footnotetext{
Визначення мети та задач дослідження

Метою досліджень $є$ отримання на основі експериментальних робіт емпіричних залежностей змін коефіцієнтів постілі дерев'яних шпал під час експлуатації колії, а також горизонтальних поперечних жорсткостей рейкових опор на дерев'яних шпалах, отримання залежностей їх змін під час експлуатації та встановлення впливу осьових навантажень на вказані параметри.

До числа головних задач, які необхідно було вирішувати при дослідженні роботи шпал під дією динамічних вертикальних та горизонтальних поперечних сил, були віднесені такі:

- визначення виду залежності між переміщеннями шпал і силами, які їх викликають або, інакше, визначення пружних характеристик шпал;

- вибір способу лінеаризації пружних характеристик для визначення жорсткостей шпал;

- визначення робочих діапазонів вживаності розрахункових значень коефіцієнтів постілі та жорсткості шпал;

- вивчення впливу вертикального навантаження на горизонтальну поперечну жорсткість шпал;
}

- дослідження змін горизонтальної поперечної жорсткості шпал у процесі експлуатації колії та встановлення чинників, що впливають на ці зміни.

\section{Основна частина}

Жорсткість дерев'яних шпал при вертикальних та горизонтальних поперечних навантаженнях i коефіцієнти постілі цих шпал для умов колій магістральних залізниць України визначені на підставі даних експериментальних досліджень, проведених у 2008 - 2009 роках.

Роботи проводилися на 12 дільницях колії.

Характеристики плану і профілю ділянок, осьові навантаження, значення вантажонапруженості i терміни служби колії після заміни решітки наведені в табл. 1.

На кожній дослідній ділянці випробовувалося від 3 до 5 шпал. Вертикальні навантаження на шпали від рухомого складу фіксувалися силомірними підкладками, вертикальні переміщення шпал відеоцифровою системою вимірювання переміщень [12]. Вертикальні сили й переміщення шпал записувалися безперервно в цифровому вигляді в пам'яті комп'ютера під час проходу всього складу.

Записана інформація копіювалася, переносилася в табличний процесор Excel. За цими даними будувались графіки залежності між переміщеннями та навантаженнями тобто пружні характеристики шпал для усереднених значень переміщень і навантажень для кожної ділянки. Пружні характеристики шпал $є$ затухаючими (жорсткими), із збільшенням навантажень вертикальна жорсткість шпал зростає (рис. 1).

Жорсткості шпал при вертикальних навантаженнях однієї рейкової нитки були визначені шляхом лінеаризації пружних характеристик методом хорд для діапазонів 25 - 40, 40 - 60 і $60-75 \kappa H$, що відповідає реальним навантаженням на шпалу при русі екіпажів 3 осьовими навантаженнями до 165,165 - 210 і більше $220 \kappa H$ на вісь.

Одержана інформація дає змогу зробити висновок про те, що із збільшенням діапазонів діючих навантажень при зіставних значеннях пропущеного по ділянках тоннажу вертикальна жорсткість залізобетонних шпал зростає. Таке збільшення для дерев'яних шпал складає від 22 - 27 до 52-59\% (рис. 1) при діапазоні навантажень 40-60 та 60-75 кН у порівнянні з діапазоном 25 - 40 кН.

Для ділянок, по яких обертається однаковий рухомий склад і які розрізняються термінами служби колії, відзначено значне збільшення вертикальної жорсткості. 
Таблиця 1

Характеристики досліджуваних ділянок, які вибрані для проведення експериментальних робіт

\begin{tabular}{|c|c|c|c|c|c|c|c|}
\hline 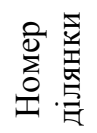 & $\begin{array}{l}\text { Тип шпал, } \\
\text { епюра }\end{array}$ & $\begin{array}{c}\text { План } \\
\text { ділянки }\end{array}$ & $\begin{array}{c}\text { Профіль } \\
\text { ділянки, } \% \text { o0 }\end{array}$ & $\begin{array}{c}\text { Осьові } \\
\text { наванта- } \\
\text { ження, } \kappa H\end{array}$ & $\begin{array}{l}\text { Швидкість } \\
\text { руху, км/2од }\end{array}$ & $\begin{array}{l}\text { Вантажона- } \\
\text { пруженість, } \\
\text { млн } \mathrm{m} / p i \kappa\end{array}$ & $\begin{array}{c}\text { Термін } \\
\text { служби } \\
\text { колії, } p p .\end{array}$ \\
\hline 1 & Дер IA 1840 & Пр & 0 & 160 & $<60$ & 7 & 2 \\
\hline 2 & Дер IA 1840 & Кр R 300м & 0 & 160 & $<60$ & 7 & 7 \\
\hline 3 & Дер IA 1840 & $\Pi p$ & 0 & 215 & $<60$ & 12 & 5 \\
\hline 4 & Дер IA 2000 & Kр R 480м & 0 & 215 & $<60$ & 12 & 9 \\
\hline 5 & Дер ІБ 1840 & Кр R 650м & 0 & 170 & $60-80$ & 5 & 5 \\
\hline 6 & Дер ІБ 1600 & $\Pi p$ & 3 & 170 & $60-80$ & 5 & 10 \\
\hline 7 & Дер IA 1840 & $\Pi p$ & 0 & 210 & $<40$ & 8 & 6 \\
\hline 8 & Дер IA 1840 & $\Pi p$ & 0 & 210 & $<10$ & 8 & 8 \\
\hline 9 & Дер ІБ 2000 & Кр R 450м & 0 & 200 & $60-80$ & 4 & 0 \\
\hline 10 & Дер IA 1840 & $\Pi p$ & 0 & 200 & $60-80$ & 4 & 12 \\
\hline 11 & Дер IA 1840 & $\Pi p$ & 10 & 175 & $60-80$ & 18 & 0 \\
\hline 12 & Дер IA 2000 & Кр R 280м & 10 & 175 & $80-90$ & 18 & 7 \\
\hline
\end{tabular}

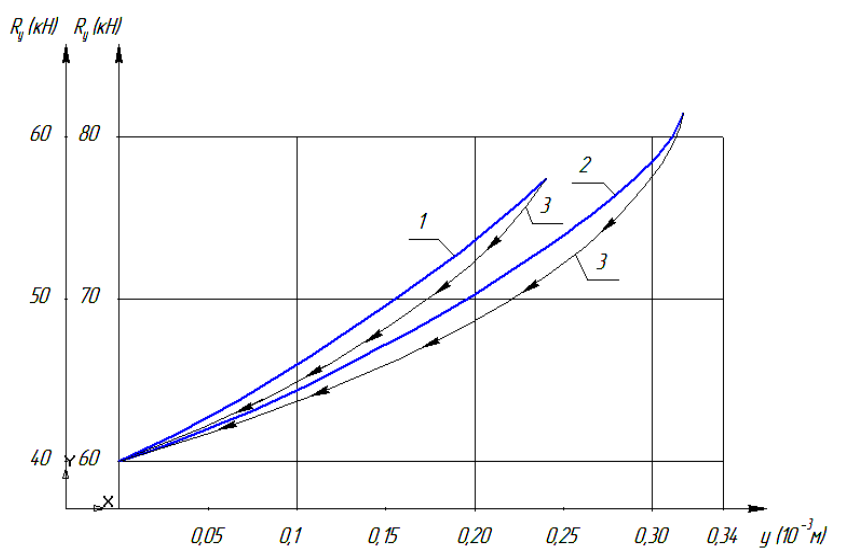

Рис. 1. Пружні характеристики шпал при вертикальних навантаженнях:

$1-P_{o c}=215 \kappa H / в i c b$, термін служби колії 5 років, тоннаж - 60 млн $m$;

$2-P_{o c}=215 \kappa H / в i c b$, термін служби колії 5 років, тоннаж - 90 млн $m$;

3 - пружні характеристики при розвантаженні

Можна припустити, i це припущення підтверджується проведеними експериментальними роботами, що на зміни жорсткостей шпал при вертикальному навантаженні й на коефіцієнт постілі шпал значно впливає саме кількість пропущеного по ділянках тоннажу як узагальнюючого чинника силової дії на колію. У міру зростання тоннажу відбувається збільшення щільності й засміченості баласту, що й викликає зростання сил опору шпал переміщенням.

Коефіцієнт постілі шпал, $\kappa H / \mathrm{s}^{3}$, визначався на підставі дослідних даних як

$$
C_{z \sigma}=\frac{R_{z}}{\alpha \Omega_{u} z_{p}},
$$

де $R_{z}$ - діюче на шпалу вертикальне навантаження, $\kappa H$;

$\Omega_{\Psi}$ - площа полушпали, $\mu^{2}$;

$z_{p}-$ вертикальне перемішення шпали в підрейковому перерізі, $м$;

$\alpha$ - коефіцієнт вигину шпали.

У рівнянні (3) при використовуванні як аргументів даних про зміни значень $R_{z}$ i $z_{p}$, які одержані експериментально, невідомими залишаються два

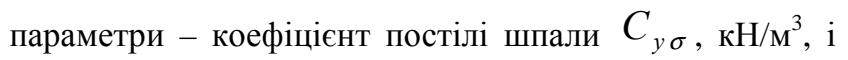
коефіцієнт вигину шпали $\alpha$. Коефіцієнт вигину шпали, що $\epsilon$ відношенням середнього осідання шпали до осідання в підрейковому перерізі, у свою чергу залежить від навантажень, що діють на шпалу, геометричних характеристик шпали, пружних властивостей іiі матеріалу й коефіцієнта іiї постілі. 


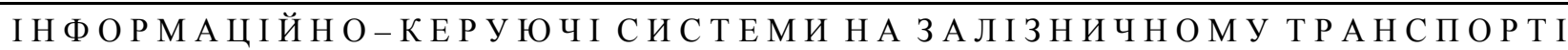

Раніше наголошувалося, що значення коефіцієнта $\alpha$, одержані в різних дослідженнях, значно розрізняються й недетерміновані за умов їх застосовності, наприклад, по величині коефіцієнта постілі шпали.

Визначення параметрів $C_{\sigma}$ і $\alpha$ можна розглядати розрахункових значень прогинань шпал у підрейковому перерізі:

$\mathcal{E}=\sum_{i=1}^{i=n} \frac{z_{p i}-z_{p \ni i}}{z_{p i}} ; z_{p i} \neq 0$,

як ідентифікацію об'єкта заданої структури. Тут математична модель об'єкта задається рівнянням (3) й методикою розрахунку шпали як балки змінного перерізу, що лежить на суцільній пружній основі, яка характеризується коефіцієнтом постілі шпали. Параметри цієї моделі $C_{\sigma}$ і $\alpha$ підбираються так, щоб при заданому вході (значення вертикальних сил $R_{y}$ ) вихід моделі мало відрізнявся від експериментально визначеного виходу.

Знаходження невідомих параметрів у вигляді напівемпіричної функції проводилося одним з методів пошуку екстремуму цільової функції $\alpha=f\left(C_{\sigma}\right)$ методом покоординатного спуску [13]. Як цільова функція приймалася величина, рівна сумі квадратів відносних відхилень експериментальних і

де $z_{p i}$ - величина вигину шпали, визначена розрахунковим шляхом при

значенні $R_{z}, \mu$;

$z_{p \text { эi }}-$ те ж, визначена експериментально, $\boldsymbol{M}$;

$n$ - кількість експериментальних точок.

Проведені експериментальні роботи, статистична обробка одержаних результатів і розрахунки, виконані за зазначеною методикою 3 використанням комп'ютерної програми системи Mathcad дали змогу визначити значення коефіцієнтів постілі дерев'яних шпал і коефіцієнтів їх вигину (табл. 2). Значення середньоквадратичних відхилень коефіцієнтів постілі містяться в межах $13 \%$.

Таблиця 2

Коефіціснт постілі й коефіціснти вигину шпал на дослідних ділянках

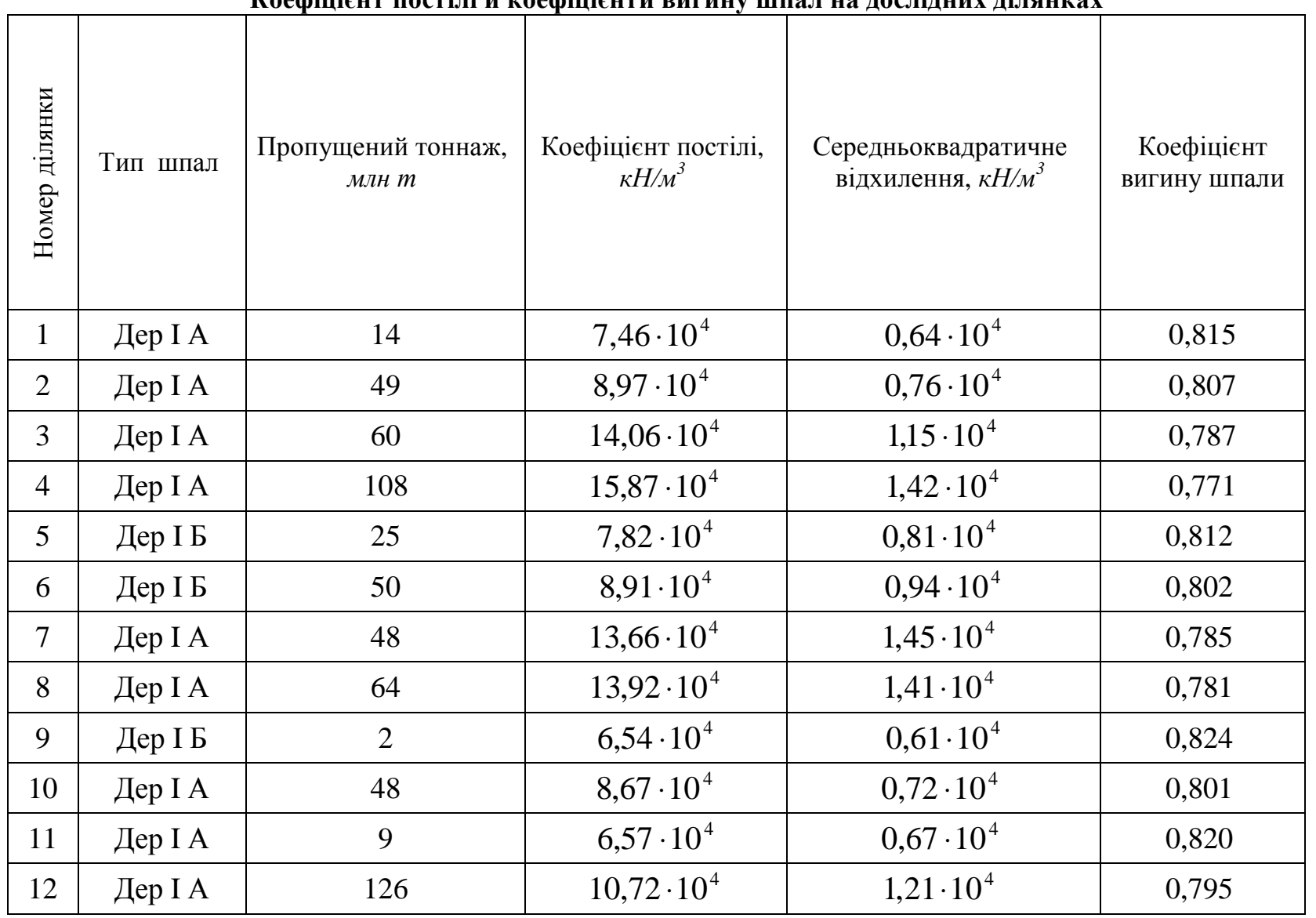




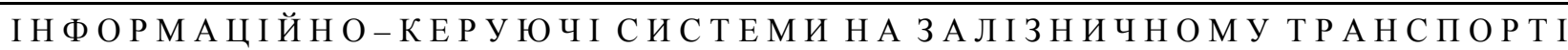

Для ділянок колії з осьовими навантаженнями 210 $\kappa Н$ значення коефіцієнтів постілі шпал і коефіцієнтів їх вигину узгоджуються 3 даними, наведеними в [3-7].

На підставі даних, наведених у табл. 2, одержана залежність змін коефіцієнтів постілі дерев'яних шпал від величини пропущеного по колії тоннажу 3 урахуванням діапазонів вертикальних навантажень на шпали.

Для дерев'яних шпал ця залежність має такі параметри, $\kappa H / \mathrm{M}^{3}$ :

$$
C_{\sigma}=K_{o c}\left(6,5 \cdot 10^{4}+0,23 \cdot 10^{4} T^{0,605}\right),
$$

де $K_{\text {ос }}$ - коефіцієнт, який ураховує рівень осьових навантажень, при осьових навантаженнях до $165 \kappa H$; $K_{\text {oc }}=1,24$ при навантаженнях 165 - $210 \kappa H$; $K_{o c}=1,55$ при навантаженнях більш $210 \kappa H$;

$T$ - пропущений по ділянці тоннаж, млн $m$.

Напівемпірична залежність коефіцієнта вигину шпали від коефіцієнта їі постілі має вигляд

$\alpha=0,9222\left(C_{\sigma} \cdot 10^{-4}\right)^{-0,0627}$ (можна використовувати для діапазону $\left.C_{\sigma}=0,6-2,2 \cdot 10^{-4} \mathrm{KH} / \mathrm{m}^{3}\right)$.

Роботи 3 визначення опірності дерев'яних шпал вертикальним переміщенням, виконані в зимових умовах у 2009 році на ділянках № 11, 12, показали, що збільшення коефіцієнта постілі для дерев'яних шпал в 1,6 рази взимку є обгрунтованим.

Для лінеаризації горизонтальних поперечних пружних характеристик і визначення горизонтальної поперечної жорсткості шпал застосовувався метод хорд, при цьому як робочі діапазони лінеаризації були використані значення пружних переміщень. Для дерев'яних шпал $0-1,2$ мм для прямих, 0,5 - 1,5 мм для кривих радіусом до 450 м і 0,8 - 1,7 мм для кривих менших радіусів. Такі діапазони прийняті виходячи 3 аналізу реальних переміщень шпал у колії, одержаних експериментально.

У таблиці 3 наведені значення горизонтальної поперечної жорсткості дерев'яних шпал, одержаних у результаті статичної обробки даних експериментальних робіт на дослідних ділянках. Середньоквадратичні відхилення цих параметрів містяться в межах $7-14 \%$. Значний розкид даних для дерев'яних шпал пояснюється, мабуть, широким діапазоном механічних характеристик деревини.

Таблиця 3

Горизонтальна поперечна жорсткість шпал на досліджуваних ділянках

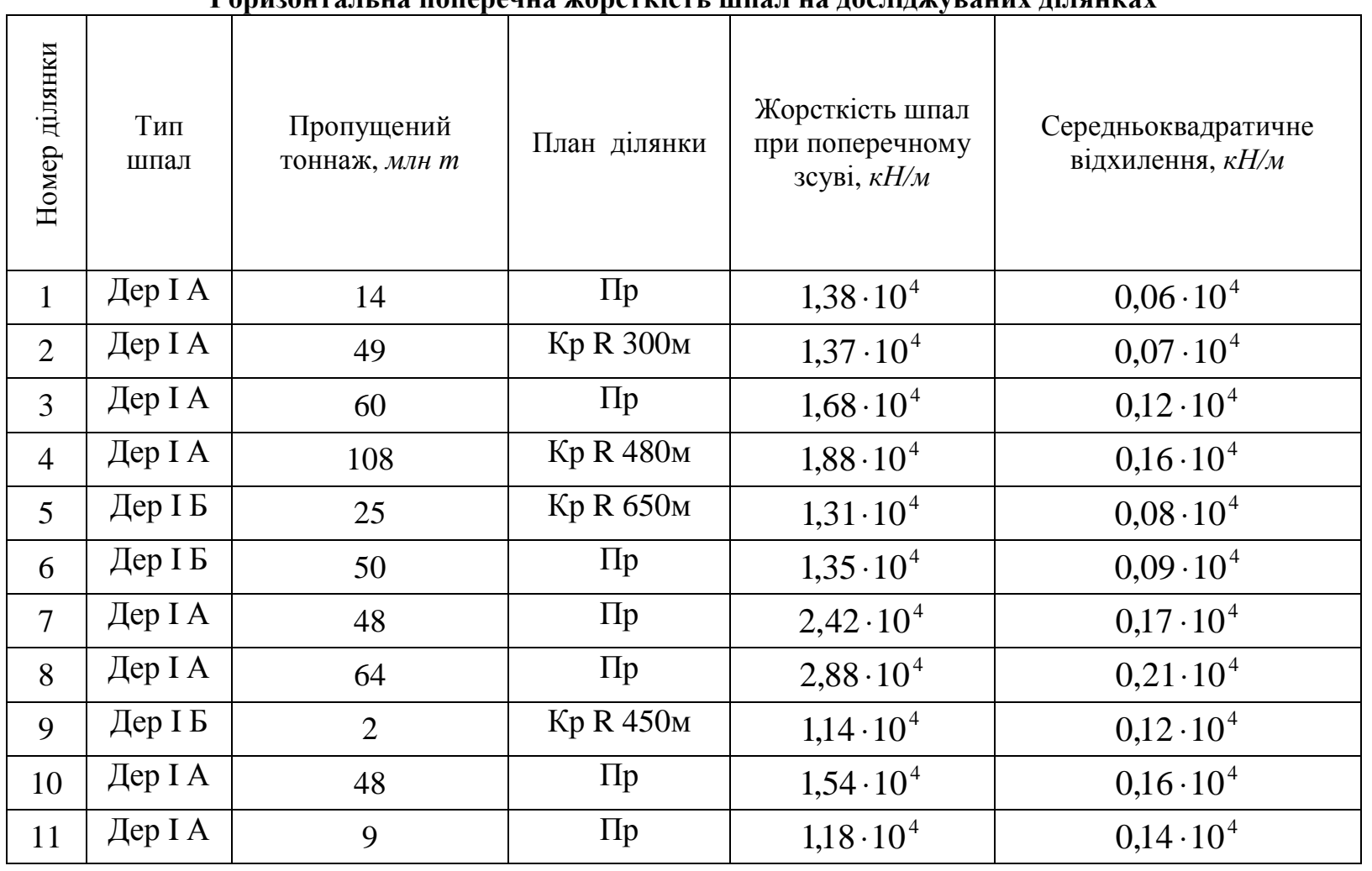


Залежності жорсткості шпал при поперечному зсуві від величини вертикальних навантажень на шпали та пропущеного по колії тоннажу апроксимовані рівнянням виду

$C_{z}=\left(a+8 p_{z}^{c}\right) \cdot f(T)$,

де $p_{z}$ - вертикальні навантаження від двох рейок на шпалу, $\kappa H$; млн $m$;

$f(T)$ - вплив пропущеного по ділянках тоннажу,

$a, b, c$, - емпіричні коефіцієнти.

Із зростанням пропущеного по ділянках тоннажу горизонтальна поперечна жорсткість дерев'яних шпал зростає.

Iз зростанням пропущеного по ділянках тоннажу від 90 до 180 млн т. горизонтальна поперечна жорсткість дерев'яних шпалах змінюється від $1,025 \cdot 10^{4}$ до $1,21 \cdot 10^{4} \kappa H / \mathcal{M}$ (18\% збільшення).

Експериментальні роботи, виконані у 2009 році на ділянках № 11, 12, дали змогу встановити, що в зимових умовах горизонтальна поперечна жорсткість дерев'яних шпал зростає в 1,8 разу.

3 урахуванням вищевисловленого була встановлена залежність змін горизонтальної поперечної жорсткості шпал при різному рівні вертикальних навантажень на шпалу й при збільшенні пропущеного по ділянках тоннажу.

Для дерев'яних шпал залежність змін горизонтальної поперечної жорсткості, $к H / м$, має вигляд

$$
C_{z u}=K_{3}\left(0,24 \cdot 10^{4}+0,18 \cdot 10^{4} \cdot P_{y}^{0,348}\right)\left(1+0,019 T^{0,690}\right),
$$

де $K_{3}$ - коефіцієнт, для літніх умов дорівнює 1 , для зимових умов дорівнює 1,8 ;

$P_{y}-$ вертикальне навантаження від двох рейок на шпалу, $\kappa H$;

$T$ - пропущений по ділянці тоннаж, млн $m$.

\section{Висновки}

1 Розглянуто формування сил опорів просторовим переміщенням дерев'яних шпал. Визначені умови прояву і співвідношення пружних і дисипативних сил у структурі загальних опорів.

2 Виконані експериментальні дослідження пружних характеристик дерев'яних шпал при їх навантаженні в колії вертикальними і горизонтальними поперечними силами.
3 Отримані значення відповідних жорсткостей шпал, встановлені залежності їх змін у процесі експлуатації колії. Визначений вплив експлуатаційних характеристик колії на параметри, що досліджувались.

4 Для умов, зіставних з експлуатаційними умовами українських залізниць, одержані іншими дослідниками дані узгоджуються 3 даними, які отримані авторами.

\section{Лiтература}

1. Новичков, В.П. Рациональные способы усиления железнодорожного пути [Текст] / В.П Новичков // Ж. - д. трансп. - 1956. - № 4. - С. 66 - 68.

2. Kim, S. J. A Study on the Running Safety of F26 Turnout and Vehicle Model [Electronic resource] / S. J. Kim, B.-G. Eom, H. S. Lee // International Journal of Railway. - 2012. - Vol. 5, № 4. - P. 156162. - Available at: http://www.ijr.or. kr/On_line/admin/files/(156- 162)-12-024.pdf. - Title from the screen. - Accessed: 15.03.2016.

3. Даніленко, Е.І. Правила розрахунків залізничної колії на міцність i стійкість [Текст] / Е.I. Даніленко, В.В. Рибкін. - К.: Транспорт України, 2006. - 168 с.

4. Иволга, Н.В. Об инерционных свойствах пути при движении по нему постоянной силы [Текст] / Н.В. Иволга, В.И. Климов // Труды ДИИТа. - 1975. - № 167/16. - С.73 - 81 .

5. Васютынский А.А. Наблюдения над временными деформациями верхнего строения пути на Варшаво- Венской железной дороге [Текст] / А.А Васютынский // Труды XV съезда инженеров службы пути. - М., 1858. - С. 12 - 17.

6. Стецкевич, И.Р. Об опытах над устойчивостью верхнего строения пути при проходе поездов [Текст] / И.Р. Стецкевич // Протоколы XII совмещенного съезда инженеров службы пути русских железных дорог. - М., 1894. - С.65 - 72.

7. Рубан, П.С. Методика работ по определению коэффициента постели шпал [Текст] / П.С. Рубан // Институт инженерных исследований НКПС М.: Транспечать, 1930. - Вып. 27.

8. Сергеев, Б.Н. Упрощенные методы полевых испытаний рельсового пути [Текст] / Б.Н. Сергеев // Труди НИИ пути. - М.: Госжелдориздат, 1933. C. 9- 27.

9. Вериго, М.Ф. Определение динамического модуля пути [Текст] / М.Ф. Вериго // Техника железных дорог. - 1949. - № 12. - С. 23 - 24.

10. Современные конструкции верхнего строения железнодорожного пути [Текст] // под ред. В.Г. Альбрехта и А. Ф. Золотарского. М.: Транспорт, 1975. - 280 с.

11. Содержание балластной призмы железнодорожного пути [Текст] / под ред. Е.С. Варызгина. - М.: Транспорт, 1978. - 141 с. 
12. Система для вимірювання переміщень в елементі інженерних конструкцій i споруд під дією навантажень [Текст]: пат. 70477 Україна: МПК G05D 5/00; E01B 35/00 / Даренський О.М., Астахов В.М., Бугаєць Н.В., Витольберг В.Г., Беліков Є.А.; власник Укр. держ. акад. залізнич. трансп. - № u 201114788; заявл.13.12.2011; опубл. 11.06.2012, Бюл. № 11. - 14 с.

13. Дуглас, Дж Уайд. Методы поиска экстремума [Текст]: монография / Дж Уайд Дуглас. М.: Наука, 1967 - 216 с.

Тулей Ю.Л. Математическое моделирование и экспериментальные исследования работы деревянных шпал под действием пространственных нагрузок. В статье приведены результаты экспериментальных работ из исследований упругих сопротивлений деревянных шпал пространственным перемещением под действием нагрузок от подвижного состава. Полученные эмпирические зависимости изменений коэффициентов постели деревянных шпал, коэффициентов их изгиба и горизонтальной поперечной жесткости во время эксплуатации колеи. Учтены другие условия эксплуатации, в первую очередь уровень действующих осевых нагрузок.

Исследование пространственных сил взаимодействия колеи и подвижного состава позволяет не только получать численные их значения, но и целеустремленно влияя на характеристики колеи и подвижного состава достигать оптимальных значений этих сил.

Ключевые слова: диссипативные характеристики, деревянные шпалы, горизонтальная поперечная жесткость, подвижной состав.

Tuley J.L. Mathematical modeling and experimental research wooden sleepers work under spatial loads. The article presents the experiment results of investigation into elastic resistances of wooden sleepers to spatial transfer under the load from the rolling stock. The empirical dependencies of changes in coefficients of subgrade resistance for wooden sleepers, coefficients of curvatures for wooden sleepers and coefficients of horizontal lateral stiffness in track operation have been obtained. The other operation conditions, first of all, the level of working axle loads have also been taken into consideration.

The researches into spatial forces of interaction between the track and the rolling stock make it possible to obtain the values of these forces and achieve the optimal values by purposefully influencing the track and rolling stock characteristics. These researches can be conducted through experiments requiring considerable expenditures, and numerical methods using mathematical models and techniques.
In order to apply numerical investigation it is necessary to have reliable data on elastic dissipative track characteristics, obtained through numerical experiments, components of which are elastic resistances of sleepers under the impact from spatial forces.

Key words: dissipative characters, wooden sleepers, horizontal lateral stiffness, rolling stock.

Рецензент д.т.н., професор Даренський О.М. (УкрдУЗТ)

Надійшла 04.07.2016 p.

Тулей Юзеф Леонідович, начальник Департаменту колії Укрзалізниці.

Tuley Yusef Leonidovih, head of the Department track, Ukrzaliznytsia. 